\title{
Effect of Fees Policies on the Quality of University Education in Uganda
}

\author{
Wilson Muyinda Mande ${ }^{1, *}$, Margaret Nakayita ${ }^{1}$ \\ ${ }^{1}$ Nkumba University [* Corresponding author: mandewm@yahoo.com]
}

\begin{abstract}
This paper reports on the findings of a study that was undertaken to analyse the effect of fees policy on the quality of university education in Uganda. It reports that every university in Uganda has a fees policy and that these fees policies differ in content and implementation. The paper confirms a significant relationship between fees policies and the reputation of universities. It also reports that fees policies had a significant effect on the quality of education provided by the universities. Subsequently, the paper discusses the main higher education funding models in the country with specific reference to these findings. This is with the conclusion that the country should adopt an egalitarian cost sharing model that resolves the limitations of the current funding models.
\end{abstract}

Keywords: Funding; Student fees; Reform.

\section{$1 \quad$ Introduction}

This study was conducted to investigate the effect of fees policy on the quality of university education in Uganda. It can be contended that the term fees refers to the expenses a student incurs in order to access education. In higher education, the expenses a student incurs include: tuition, functional fees, accommodation, charges for special projects like research, ICT facilities, medical, National Council of Higher Education fees and graduation fees. University fees policies concern themselves with these fees and the ways in which they are paid or waived (cf. Makerere 2007, UCU 2008, Malta University, 2009, Kyambogo 2013, Griffith 2014, Nkumba, 2013).

University policies can be said to have emerged during the medieval period in Europe. Some of the universities like the University of Paris collected two sous weekly in tuition under Pierre le Mangeur (Wikipedia, 2013). It is right to contend therefore that fees policy at university level started in a humble 
manner. However, the situation has metamorphosed over the years. The world's top universities charge equally top fees as indicated in Table 1.

Table 1: Undergraduate Tuition Fees at selected Top Universities (USD)

\begin{tabular}{lc}
\hline University & Annual tuition \\
\hline Massachusetts Institute of Technology (MIT) & 36,000 \\
Harvard University & 38,891 \\
University of Cambridge & 14,000 \\
University College London (UCL) & 14,000 \\
Imperial College London & 14,000 \\
University of Oxford & 14,000 \\
Stanford University & 42,690 \\
Yale University & 43,100 \\
University of Chicago & 45,324 \\
California Institute of Technology (Caltech) & 39,990 \\
Princeton University & 40,170
\end{tabular}

Source: http://www.topuniversities.com

It is important to remember that the figures in the above table do not include costs of rent, food, textbooks, and computers. The UK based universities charge slightly less because public universities are allowed to charge up to $£ 9000$ which is about US\$14000 (Byrne, 2013). These top universities have excellent reputation among employers globally. The fact that the top universities charge top fees, it goes without saying that quality university education comes at a high cost.

In Uganda, the state bore the entire cost of university education until the mid-1980s. There were no private universities. It was during the mid-1980s that private universities emerged in the country (Kavuma, 2011). These became the fee-charging universities. Public universities also formulated policies under which they began to charge fees.

There is a widely held view that the higher the cost the better the quality of university education (Mendenhall, 2012). However, there are dissenting opinions on this matter. For instance there are those who are strongly opposed to "the harvardisation" of university education because it is ruinous (Taylor, 2012). In Uganda, government barred public universities from increasing student fees (Namutebi, 2013).

At the private universities, tuition fees have been increased for new entrants (Kwesiga \& Anguyo, 2013). Students in both public and private universities have intermittently opposed fees policies that increased the cost of university education (Table 2). 
Table 2: Incidence of Student Strikes Protesting Fees Increments (2008-2014)

University

Makerere University

Gulu University

Mbarara University of

Science

Kyambogo University

Makerere University

Business School

Ndejje University

Nkumba University

Kampala International

University

Kumi University

Uganda Christian

University

Mutesa I Royal University Private

Sources: Kayiira (2008), Habati (2011), Businge (2012), Nakayita (2013),

Odeng (2013), Nteza (2014) and Ahimbisibwe and Namagembe (2014).

Ironically, the same students who are opposed to increases in university fees are interested in better quality university education. Against this background, it is apposite to analyse the relationship between cost and quality of university education. This study undertook to conduct this analysis, specifically looking at: 1) the effect of fees policy on reputation of a university; 2) the relationship between reputation and quality of university education; and 3) the effect of fees policy on quality of education in Ugandan universities. In conducting the study, it was hypothesised that: 1) fees policy has a significant effect on the reputation of a university; 2) there is a significant relationship between the reputation and quality of universities; and 3) fees policy has a significant effect on the quality of university education. The conceptual relationships hypothesised between the variables involved in the study are delineated in Figure 1.

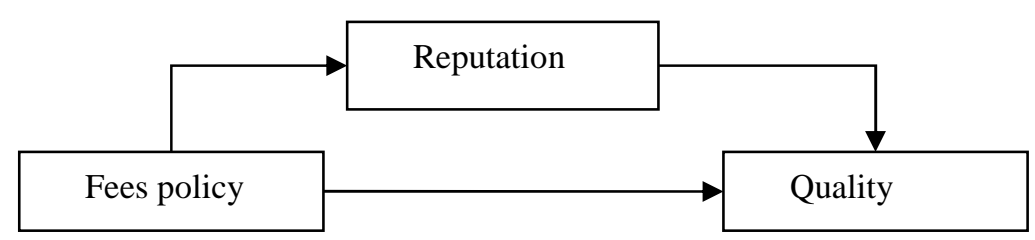

Figure 1: Conceptual Model for the Study of Fees Policy and Quality of University Education 


\section{$2 \quad$ Methodology}

The students who participated in the study hailed from 11 universities. Five of these were public and the remaining six were private. The total number of respondents was 311 . The sample of 311 was considered sufficient following the rule of thumb, which states that in social science research, any sample between 30 and 500 can produce credible results (Roscoe, 1975). Data were collected using a structured questionnaire. Apart from the items on the demographic characteristics of the respondents, the rest of the items were on the Likert type scale (i.e. "Strongly Disagree" = "1"; "Disagree" = "2"; "Neither disagree nor agree" = "3"; "Agree" = "4"; and "Strongly agree" = "5". This scale served as a measurement for the effect of fees policy on reputation, the effect of reputation on quality and the effect of fees policy on the quality of university education. An expert rated the validity of the items in the questionnaire, indicating a Content Validity Index of 0.873. Cronbach's alpha coefficient for the reliability of the instrument was established at .911, meaning that the instrument was internally consistent. The data were analysed at the level of confidence $p=.01$ using Pearson's Correlation test and regression analysis.

\section{$3 \quad$ Findings, Discussion and Recommendation}

The first hypothesis focused on the effect of fees policy on reputation. To obtain results for this hypothesis, two tests were carried out: First a Pearson's Product Moment Correlation was performed and it emerged that there was a positive significant relationship between fees policy and reputation $[\mathrm{r}$ (311) $=671, \mathrm{p}<0.01]$. This meant that good fees policies give reputation to universities. The hypothesis was further subjected to regression analysis. The results were that there is a linear relationship between fees policy and reputation $[\mathrm{F}(1,309),=253.549, \mathrm{p}<0.01]$. This suggests that changes in fees policies lead to change in a university's reputation. The Adj. $\mathrm{R}^{2}$ from the simple linear regression matrix model was 0.449 , meaning that fees policy explains $45 \%$ of the reputation of a university. Accordingly, the hypothesis that there is no significant relationship between fees policy and reputation of a university was rejected.

In order to identify the factors that make up reputation for the University a factor analysis was carried out. The results are given in Table 7 below. The principal factors were extracted using the rotation method of Varimax with Kaiser Normalisation. 
Makerere Journal of Higher Education

Table 3: Total Variance Explained

Component Initial Eigenvalues

Extraction Sums of Squared Loadings Rotation Sums of Squared Loadings

Total \% of Variance Cumulative \% Total \% of Variance Cumulative \% Total \% of Variance Cumulative \%

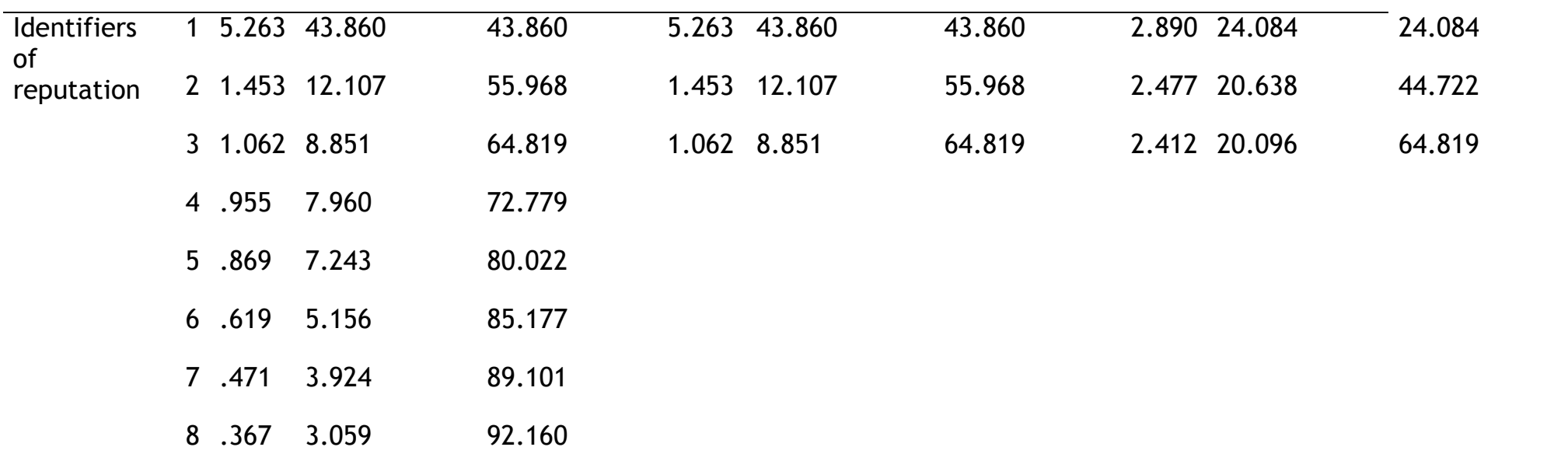

Extraction Method: Principal Component Analysis. 
Table 3 shows that many items were chosen to represent reputation. Out of the 8 items or cases only three emerged significant. These were the ones that carried an eigenvalue exceeding one. Applying the rotated matrix with Kaiser Normalization, the principal components were extracted as discussed below.

1. Parents and alumni perception of the reputation of a university. This factor was explained by several main variables: "my parents wanted me to study here" with a coefficient of .781 measured the factor quite highly. The factor was also measured by "friends extolling the reputation of a university". This had a coefficient of .730. The fact that students get their academic papers on graduation day was another variable that contributed to the good reputation, yielding a coefficient of .616. Another variable which heightened the reputation of the universities was the knowledge that graduates get jobs soon after their graduation. This carried a coefficient of .608. The other variables which did not yield coefficient of .500 and above were considered weak explicators of the University reputation.

2. Good name of the university abroad. This factor was explained by the following items: "The university in which I am studying has a good name back home" with a coefficient of .854; current university has very good lecturers with a coefficient of .780; and the university having a very good name generally with a coefficient of .641 . The implication of all this is that what is said about the University partly influences students' attitudes towards the university.

3. Quality of academic programmes. Students believed academic programmes in the Ugandan Universities to be very good. This factor was explained by three items: preferred to study in Uganda (.814); preferred a private university to a public one (.768); and the academic programmes in this university are good (.642). With the above analysis, it is true to assert that quality of academic programmes heighten the reputation of the University.

Some academic registrars and admissions officers explained that building institution reputation costs a lot of money. Universities that have built reputation have had to spend a lot of money on facilities, staffing and publicity.

The second hypothesis stated that "there is no significant relationship between reputation and quality". This hypothesis was tested using both Pearson's correlation and a simple linear regression. The Pearson's correlation revealed that there was a moderate positive significant relationship between reputation and quality $[\mathrm{r}=.340, \mathrm{p}<0.01]$. This meant that reputation and quality go hand in hand: a university cannot have good reputation unless it offers quality education.

Simple linear regression yielded an Adj. $\mathrm{R}^{2}$ of .330 , which meant that students and other stakeholders know the quality of a university by analysing its reputation in academic work. Furthermore, the test revealed that there was 
linearity between the independent variable and the dependent one $[\mathrm{F}(1,309)$ $=1676.137, \mathrm{p}<0.01]$. The results of the regression matrix also confirmed the positive relationship between reputation and quality (Beta $=.340, \mathrm{p}<0.01)$. This meant that reputation leads to quality in situations where philanthropists and organisations usually prefer to fund reputable universities so that they continue offering quality education. In Uganda, reputable universities like Makerere attract more funding from multilateral and bilateral donors. This enables them to offer quality education.

Pearson's correlation test was conducted to test the hypothesis that "fees policy has a significant effect on the quality of university education". The test revealed a strong positive significant relationship between the reputation and cost of a university $[\mathrm{r}=.361, \mathrm{p}<0.01]$. These results indicate that generally where the fees policy is good, there should be quality education. A university has to spend money to make quality possible. Money comes from fees levied according to a specified policy. The regression coefficients results of Beta = $.361, \mathrm{p}<0.01$ indicated that fees policy had effect on quality of university education in Ugandan universities.

A hypothetical model was used to determine the overall effect of fees policy on quality of university education. The hypothetical model therefore provides a reliable explanation that quality is a function of fees policy, that is, $Q=f(F P)$. In the explanation the following are taken into account:

1. Determining variables - in the model there is an independent variable (fees policy), and intervening variable (reputation), and a dependent variable (quality).

2. Establishing causal paths - the causal paths relevant to variable (3) which is quality of university education are paths from (1) to (2) to (3); and from (1) to $(3)$.

3. Stating assumptions - e.g. all relations are linear,

4. Variables are measured linearly left to right.

The paths for the hypothesised empirical model are shown in Figure 2.

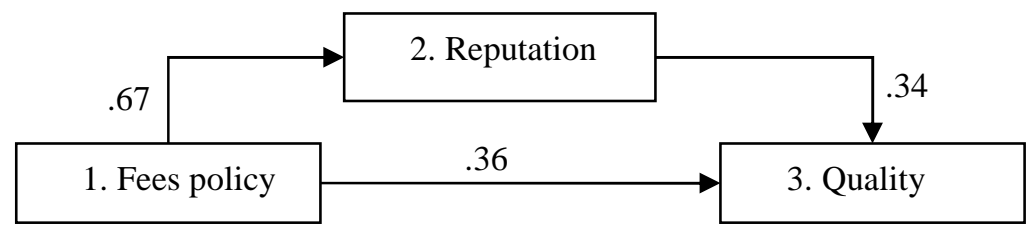

Figure 2: Hypothesised Empirical Model

The paths shown in Figure 2 establish three relationships: a positive significant relationship between fees policy and reputation; a positive significant relationship between reputation and quality; and a positive significant 
relationship between fees policy and quality. Variable 1 (fees policy) is the only exogenous variable because it has no arrows pointing to it. This leaves two endogenous variables in the model, that is variable 2 (reputation) and variable 3 (quality). Each of these variables is explained by one or two variables.

The paths coefficients were used to decompose correlations in the model into direct and indirect effects corresponding to direct and indirect paths reflected in the arrows of the model. This is based on rule that in a linear system the total causal effect of variable A on variable B is the sum of the values of all the paths from A to B. Quality is the dependent variable while fees policy is the independent variable, the indirect effects and calculated by multiplying the paths coefficients for each path from fees policy to quality. Accordingly, 23 is the total indirect effect of fees policy on choice of private university, plus the direct effect of .36. The total causal effect of fees policy on quality is $(.23+.36)$ .58 . In view of the above model, it is appropriate to infer that fees policy is a major determinant of the quality education. The other factors which account for the remaining .42 should be only peripheral in the matters of quality university education.

Although the total causal effect of $58 \%$ is moderate, there is some discontent about the fees paid in Ugandan universities. For instance it is argued that the fees paid by university students do not reflect the true cost of university education in the country (Kasozi, 2009). Regarding fees in most universities there a proclivity to use the method of benchmarking. There is also an element of incrementalism in fees policies of universities. This is where a university fees policy requires adding a percentage rise on fees every financial year. The incrementalism method does not necessarily reflect the true cost of the university education.

There have been several funding models for university education. The first model was complete free university education. This was in place until the early 1990s. However, this model appears to have proved unsustainable. In the wake of liberalisation policy, government shifted the burden of financing university education to parents. Even though the government sponsors some 4000 students annually, it does not cover the full cost of tuition and boarding (Mamdani, 2007). This situation gave birth to the second model which is fully-selfsponsored students regardless of whether they are at public or private universities. Students or parents meet all the expenses at the university. Consequently, about 70 percent of the students who qualify to join university miss out. They just cannot raise the fees. This is model has not been successful either. It cannot take Uganda to great levels of development if only 30 percent of the qualifying citizens manage to acquire university education.

In view of the limitations of models 1 and 2, government introduced a third model, which is a student loan scheme. Although it is a popular way forward, it has already shown some limitations. It is limited to those offering science 
programmes at public and chartered private universities. Moreover, with a high rate of graduate unemployment, it is likely that those who will get the loans may find it hard to repay as expected.

Given these limitations, we propose an egalitarian model of cost sharing. This is a model where all students in the public and chartered universities have all their tuition underwritten by the state while the other expenses are paid by parents and students. This should cut across all universities that are recognised and across all academic disciplines without discriminating against those that are not science based.

\section{References}

Ahimbisibwe P. and Namagembe (2014) Police Backs Makerere University students. In the Daily Monitor. 15 $5^{\text {th }}$ July. No 196.

Bennington, L. and Cummane, J. (1998), "Measuring Service Quality: a Hybrid methodology", Total Quality Management, Vol. 9 No. 6, pp. 395-405.

Byrne, D (2013) "Tuition Fees at the World's To Universities". http://www.topuniversities.com/ student-info/student-finance/how-muchdoes-it-cost-study-us

Court, David. (1999). Financing Higher Education in Africa: Makerere, the Quiet Revolution. In http://www.worldbank.org/afr/findings/english/find143.htm

Fields, J.C. (1994), Total Quality for Schools: A Guide for Implementation, ASQC Quality Press, Milwaukee, WI.

Frazer, M. (1994),"Quality in higher education: an international perspective", in Green, D. (Ed.), What is Quality in Higher Education? SRHE and Open University Press, Buckingham

Griffith University (2014) Fees and Charges Policy. http://policies.griffith.edu.au

Habati M A (2011) Makerere University Fees will not be increased, In the Independent.

http://www.collegeconfidential.com/college_admissions/cost_of_college.htm

Kasozi A.B.K., (2003), "University Education in Uganda: Challenges and Opportunities for Reform".

Kasozi A.B.K., (2009), "Financing Uganda's Public Universities: An Obstacle to Serving the Public Good", The Decline of Public Funding for Higher Education, 1970-2005 pp.27-28.

Kasozi, A.B.K. (2006). The Politics of Fees in Uganda. International Higher Education. http://www.bc.edu/bc_org/avp/soe/cihe/newsletter/htm 
Kavuma R M (2011) "In Africa's universities, quantity threatens quality". http://www.theguardian.com/ global-development/povertymatters/2011/sep/09/africa-university-funding-crisis

Kwesiga P and Anguyo I (2013) Universities Hike Fees. In The New Vision. Available at: www.newvision.co.ug.

Malta University (2009) "University Fees Policy Guidelines." Finance office. http://www.um.edu.mt.../ feespolicyguidelines 2013/2014

Mamdani M, (2007), Scholars in the Marketplace: The Dilemmas of NeoLiberal Reform at Makerere University, 1989-2005. Kampala: Fountain Publishers.

Mande W M (2007) Quality Pedagogy as a modified constructivism. In Nkumba University Educational Bulletin. Entebbe. Nkumba University

Mande W M (2009) The Effect of Cost on the Quality of MBA programmes in Ugandan universities. In Makerere Journal of Higher Education. Kampala Uganda

Nakayita M (2013) The cost of university education and choice of private universities in Uganda by international students. A case of Nkumba and Kampala International Universities. Unpublished MBA dissertation. Entebbe: Nkumba University

Namutebi J (2013) Tuition policy, MPs summon Makerere University Council. http://allafrica.com/ stories/201303281352.html

Nkumba University (2013) Fees Policy Manual. Unpublished

Nteza M (2014) Makerere Students Strike Again. http://chimpreports.com/index.php/news/ eye-reports/19143-photosmakerere-students-strike-again.html

Roscoe J T (1975) The Fundamental research statistics for the behavioural sciences. $2^{\text {nd }}$ Edition. Holt, Rinehart and Winston. New York.

Taylor A (2012) Harvard is ruining the world's youths. http://www.businessinsider.com/french-professor-harvard-is-ruining-theworlds-youth-2012. 